\title{
Effect of Liquid Smoke as Antibiotic Replacer on Ileal Characteristic and Intestinal Microflora in Broiler Chicken
}

\author{
Eko Widodo, Derana Tri Mustikawatie, Bayu Aji Pradikdo, M. Halim Natsir, Edhy Sudjarwo
}

\begin{abstract}
Liquid smoke has not been used as antimicrobial agents in poultry feed. Therefore, the purpose of this research was to evaluate the effect of liquid smoke from coconut shell on the ileal characteristics and microflora population in broiler chicken. The method was in vivo experiment by using Completely Randomized Design. One-hundred-and-forty-day old chicken of strain Cobb allocated into 4 treatments and 5 replications. The treatments consisted of $T 0=$ basal feed added with antibiotic. $T 1=$ basal feed $+0.5 \%$ liquid smoke, $T 2=$ basal feed $+1 \%$ liquid smoke, and T3=basal feed $+1.5 \%$ liquid smoke . The measured variable was: ileal length and weight, $p H$ and viscosity of ileal content, population of microflora consisted of Lactobacillus, Escherichia coli, dan Salmonella sp. Data were analyzed with ANOVA and if significant result was obtained then continued with Duncan's multiple range test. The results showed that there were no significant different $(P>0.05)$ effect of treatment on intestinal characteristic values, but it significantly affected $(P<0.01)$ all microflora population. Conclusion of this research was addition of smoke liquid up to $1.5 \%$ does not cause a negative effect on intestinal characteristics, but improve non-pathogenic microflora population in broiler chicken. It might suggest that liquid smoke could be consider to replace the use of antibiotic in broiler feed.
\end{abstract}

Keywords: Liquid smoke, ileal villi, microflora, and broiler.

\section{INTRODUCTION}

$\mathrm{U}$ nder current situation, Indonesian broiler farmers have to face many difficulties, such as fluctuated price, climate change, increasing price of inputs such as feed, day old chick, equipment, vaccine and medicine, spread of diseases under traditional system, consumer concern with regard to antibiotic residues in meat products. The government have been pushed to release a policy to ban the use of antibiotic in broiler feed from January 2018 to ensure production of healthy meat product for people. Since European and other developed countries have long been implemented such policy, they have used some natural products as antibiotic replacer. The importation of antibiotic

Revised Manuscript Received on January 5, 2020.

* Correspondence Author

Eko Widodo*, Lecturer, Faculty of Animal Science, Brawijaya University, Malang, East Java, Indonesia. Email: eko.widodo@ub.ac.id

Derana Tri Mustikawatie, ${ }^{2}$ Undergraduate Student, Faculty of Anima Science, Brawijaya University, Malang, East Java, Indonesia.

Bayu Aji Pradikdo, Postgraduate Student, Faculty of Animal Science, Brawijaya University, Malang, East Java, Indonesia.

M. Halim Natsir, Lecturer, Faculty of Animal Science, Brawijaya University, Malang, East Java, Indonesia.

Edhy Sudjarwo, Lecturer, Faculty of Animal Science, Brawijaya University, Malang, East Java, Indonesia. products to Indonesia will increase feed production cost.

Elaboration of indigenous herbs as candidate for antibiotic replacer has been carried out by several Indonesian researchers with limited of success. Interest in the use of liquid smoke as antimicrobial agent has been implemented in food product and preservation technological aspects. However, limited research was done to implement liquid smoke as antimicrobial agent in poultry feed. Active substances of liquid smoke from coconut shell has been reported to contain $3.13 \%$ [1] or $0.73 \%$ [2] phenol and $9.30 \%$ carboxyl with acid $\mathrm{pH}$ of 3.2 . It also indicated to exert antimicrobial effect toward some pathogenic microbes [2]. In addition, another in vitro results showed that antimicrobial effect on Lactobacillus plantarum, Salmonella, Escherichia coli, dan Saccharomyces cerevisiae [3]. It is expected that such antimicrobial effect also occurs to inhibit or even kill pathogenic bacteria in the intestines of chicken. Considering that liquid smoke from coconut shell contained phenol and carbonyl contents which might improve ileal characteristic and microbial count of non-pathogenic bacteria lead to enhance performance of broiler. The current research aims to evaluate the change of ileal characteristic and microbial count under in vivo experiment in broiler fed feed containing gradual levels of liquid smoke.

\section{MATERIALS AND METHODS}

\section{A. Materials}

Materials used in this research were 140 DOC strain Cobb with average initial body weight of $44.07 \pm 2.14 \mathrm{~g}$. The chicks have been already vaccinated in the hatchery. Twenty-four-unit cages were used, each has size of $1 \mathrm{~m}^{2}$ equipped with feeder and drinker, lamp. The room was heated by using gasolec heater during brooding period. The basal feeds were divided into 2 types: starter feed (1-21 days) and finisher feed (22-35 days). Basal feed was formulated to meet nutrient requirements provided by Cobb nutrition management guide. The formula and nutrient content of basal feeds were described in the following Table 1.

\section{B. Experimental design}

The birds were allocated into 4 treatments and 5 replications per treatment, each replication used 7 birds. They were reared for 35 days. The experimental design was completely randomized design with the treatments given were:

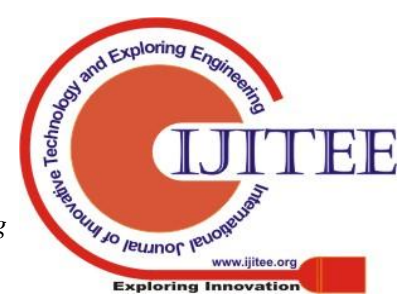


$\mathrm{T} 0=$ basal feed + antibiotic

$\mathrm{T} 1=$ basal feed $+0.5 \%$ liquid smoke

$\mathrm{T} 2=$ basal feed $+1 \%$ liquid smoke

$\mathrm{T} 3$ = basal feed $+1.5 \%$ liquid smoke

The liquid smoke used was a commercially available coconut shell liquid smoke. Feed and water were provided ad libitum during the raising period. At 35 days, 20 chickens, 1 bird in each experimental unit, were slaughtered, excised and ileal digesta content were collected, kept in test tubes and stored in deep freezer.

Table 1. Formula and nutrient content of basal feed

\begin{tabular}{|l|l|l|}
\hline Raw materials \% & Starter & Finisher \\
\hline Yellow Corn & 56 & 60 \\
\hline Soybean meal & 24.99 & 24.99 \\
\hline Meat bone meal & 9.60 & 9.60 \\
\hline Limestone & 4.60 & 4.60 \\
\hline Dicalcium phosphate & 0.12 & 0.12 \\
\hline Fish meal & 4 & 0 \\
\hline Sodium bicarbonate & 0.072 & 0.072 \\
\hline Lysine & 0.12 & 0.12 \\
\hline Salt & 0.10 & 0.10 \\
\hline Premix & 0.40 & 0.40 \\
\hline Nutrient content & \multicolumn{2}{|l}{} \\
\hline Moisture $(\%)$ & 10.36 & 10.63 \\
\hline Crude protein $(\%)$ & 23.50 & 20.10 \\
\hline Crude fiber $(\%)$ & 2.81 & 3.18 \\
\hline Crude Fat $(\%)$ & 4.55 & 4.13 \\
\hline Metabolizable energy $(\mathrm{kcal} / \mathrm{kg})$ & 3870 & 3839 \\
\hline
\end{tabular}

\section{Variables observed}

All submitted paper should be cutting edge, result oriented, original paper and under the scope of the journal that should belong to the engineering and technology area. In the paper title, there should not be word 'Overview/brief/ Introduction, Review, Case study/ Study, Survey, Approach, Comparative, Analysis, Comparative Investigation, Investigation'

The variables observed in this study were:

a) Ileal characteristics included intestinal length and weight, intestinal content $\mathrm{pH}$ and viscosity. The ileal part of intestine was taken, cut and weighed by scale, while the length was measured by ruler. The $\mathrm{pH}$ value and viscosity of ileal digesta was carried out according to the previous method [4], which was taking $1 \mathrm{~g}$ of digesta in ileal and then add with aquadest up to $10 \mathrm{ml}$ in volume. The mixture was then centrifuged at $3000 \mathrm{rpm}$ for 5-10 minutes. Supernatant from centrifugation results was separated and put into beaker glass for 2 measurements, $\mathrm{pH}$ by $\mathrm{pH}$ meter and viscosity by viscometer.

b) Total population of Escherichia coli, Salmonella sp. and Lactic Acid Bacteria (LAB). Calculation of total bacteria used the previously explained Total Plate Count (TPC) method [5].

\section{Statistical analysis}

All data obtained in this research analyzed with one-way analysis of variance (ANOVA) and continued with Duncan's
Multiple Range Test (DMRT) if there were significant differences.

\section{ReSUlts AND Discussion}

\section{A. Effect of Coconut Shell Liquid Smoke on Ileal Characteristic.}

Table 2 shows the result of coconut shell liquid smoke addition in broiler feed to the ileal characteristics

Table 2. Effect of coconut shell liquid smoke on the ileal characteristics

\begin{tabular}{|c|c|c|c|c|}
\hline Treatments & $\begin{array}{c}\text { Ileal length } \\
(\mathrm{cm})\end{array}$ & $\begin{array}{c}\text { Ileal weight } \\
(\mathrm{g})\end{array}$ & $\mathrm{pH}$ value & $\begin{array}{c}\text { Digesta } \\
\text { Viscocity }(\mathrm{cP})\end{array}$ \\
\hline T0 & $27.3 \pm 4.32$ & $9.32 \pm 1.61$ & $6.34 \pm 0.25$ & $426.8 \pm 199.7$ \\
\hline T1 & $26.1 \pm 3.70$ & $8.98 \pm 1.85$ & $6.54 \pm 0.47$ & $475.2 \pm 194.3$ \\
\hline T2 & $24.2 \pm 2.16$ & $9.92 \pm 1.44$ & $6.14 \pm 0.69$ & $340.8 \pm 128.5$ \\
\hline T3 & $24.3 \pm 2.76$ & $8.06 \pm 2.96$ & $6.64 \pm 0.15$ & $347.6 \pm 139.0$ \\
\hline
\end{tabular}

\section{B. Effect of Coconut Shell Liquid Smoke on Ileal length} and weight

Based on analysis of variance, the treatments did not show a significant effect on ileal length and weight in broiler chicken $(\mathrm{P}<0.05)$. Numerically, the data showed a tendency to decrease with increasing level of coconut shell liquid smoke in the broiler feed. The respective ileal length data from the highest to the lowest values were T0. T1. T3. and $\mathrm{T} 2$. On the other hand, no trend was indicated for ileal weight results with lowest ileal weight was $8.06 \mathrm{~g}$ (T3) and the highest was $9.92 \mathrm{~g}$ (T2). Previous report indicated that inclusion of phenolic compounds carvacol and thymol present in oregano essential oil did not influence weights of each part of broiler intestines [5].

\section{Effect of Coconut Shell Liquid Smoke on pH and viscosity values}

Based on analysis of variance, the treatments did not significantly influence averages $\mathrm{pH}$ values taken from ileal content. The results indicated that the values of ileal $\mathrm{pH}$ was almost similar, between 6.14 (T2) to 6.64 (T3). Based on analysis of variance, the treatments did also not show a significant different effect on digesta viscosity of ileum, although there is a trend of decreasing viscosity of ileal content with increasing level of coconut shell liquid smoke. Previous report indicated that viscosity of ileal content of broiler significantly reduced, but no change in $\mathrm{pH}$ value, due to addition of thymol and carvacol in broiler feed [16].

\section{Effect of Coconut Shell Liquid Smoke on Intestinal Microflora.}

The role of microflora in the intestine is important to maintain health of the chicken. The additional effect of coconut shell liquid smoke on the population of intestinal microflora in broiler is showed in Table 3. 
Table 3. Population of intestinal microflora (Lactobacillus, Escherichia coli and Salmonella sp.)

\begin{tabular}{|l|l|l|l|}
\hline Treatments & Lactobacillus $(\log$ CFU/ ml) & $\begin{array}{l}\text { Escherichia coli }(\log \text { CFU/ } \\
\text { ml) }\end{array}$ & $\begin{array}{l}\text { Salmonella sp. (log CFU/ } \\
\text { ml) }\end{array}$ \\
\hline T0 & $2.56 \pm 0.32^{\mathrm{A}}$ & $5.32 \pm 0.71^{\mathrm{A}}$ & $2.34 \pm 0.20^{\mathrm{A}}$ \\
\hline T1 & $4.30 \pm 0.15^{\mathrm{B}}$ & $6.70 \pm 0.35^{\mathrm{B}}$ & $6.30 \pm 0.64^{\mathrm{C}}$ \\
\hline T2 & $5.50 \pm 0.29^{\mathrm{C}}$ & $5.22 \pm 0.25^{\mathrm{A}}$ & $5.64 \pm 0.29^{\mathrm{C}}$ \\
\hline T3 & $7.64 \pm 0.34^{\mathrm{D}}$ & $4.54 \pm 0.60^{\mathrm{A}}$ & $3.64 \pm 0.29^{\mathrm{B}}$ \\
\hline
\end{tabular}

Notes: The different superscripts in the same row showed highly significant differences $(\mathrm{P}<0.01)$

Table 3 showed effect of treatments on averages of total non-pathogenic bacteria (Lactobacillus) and pathogenic bacteria (Escherichia coli and Salmonella sp.). Addition of coconut shell liquid smoke as natural growth promoter was expected to increase the non-pathogenic bacteria and adversely reduced the number of pathogenic bacteria. In this experiment, the highest total of non-pathogenic bacteria was shown by $\mathrm{T} 3$ which has an average was $7.64 \pm 0.34 \log \mathrm{CFU} /$ $\mathrm{ml}$, while, the lowest total of non-pathogenic bacteria was shown by $\mathrm{T} 0$ with an average of $2.56 \pm 0.32 \log \mathrm{CFU} / \mathrm{ml}$. The result of analysis of variance showed that the application of coconut shell liquid smoke in feed gave a highly significant effect $(\mathrm{P}<0.01)$ to the population of non-pathogenic bacteria (Lactobacillus). Table 3 also showed that the highest population of Escherichia coli was shown by $\mathrm{T} 1$ with an average of $6.70 \pm 0.35 \mathrm{log}$ CFU/ $\mathrm{ml}$, meanwhile the lowest population was shown by T3 with an average of $4.54 \pm 0.60 \mathrm{log} \mathrm{CFU} / \mathrm{ml}$. However, the highest number of Salmonella sp. bacteria was shown by T1 with an average of $6.30 \pm 0.64 \mathrm{log} \mathrm{CFU} / \mathrm{ml}$, but the lowest population was shown by $\mathrm{T} 0$ with an average of $2.34 \pm 0.20 \mathrm{log}$ CFU/ $\mathrm{ml}$.

Average data from the microflora population showed that the higher application of coconut shell liquid smoke leads to increase total Lactobacillus bacteria. According to previous research, the tested meat treated with coconut shell liquid smoke reduced Escherichia coli [1], similar results have been reported with in vitro tested by using Salmonella choleraeaus [2]. Total population of Lactobacillus has not been reported yet, but coconut shell liquid smoke showed antimicrobial effect toward Bacillus subtilis [1]. Current research results indicated that that under in vivo experiment, the use of coconut shell liquid smoke might be effective to improve Lactobacillus population, but it might less effective to reduce population of pathogenic bacteria in the intestines.

\section{CONCLUSION}

Based on research results, it could be concluded that addition of coconut shell liquid smoke up to $1.5 \%$ in broiler diet did not affect ileal characteristics, but population of microflora changes with preference of increasing not pathogenic bacteria, but could not decrease pathogenic ones. The result might also suggest that coconut shell liquid smoke should be combined with other antimicrobial agent which effective to reduce pathogenic bacteria so that could be promote as antibiotic replacer for broiler.

\section{ACKNOWLEDGMENT}

Authors please to acknowledge research grant from Faculty of Animal Husbandry, University of Brawijaya in the form of Hibah Doktor Lektor Kepala 2019.

\section{REFERENCES}

1. Darmaji, P. (1995) Activitas antibakteri asap cair yang diproduksi dari bermacam-macam limbah pertanian. Agritech 16, 4, 19-22.

2. Fatimah, F. (2011) Komposisi dan aktivitas antibakteri asap cair sabut kelapa yang dibuat dengan teknik pembakaran non pirolisis. Agritech 31,4, 305-311.

3. Milly, P.J., Toledo, R.T. and Ramakrisnan, S. (2005) Determination of minimum inhibitory concentration of liquid smoke fractions. Food Microbiology and Safety 70, 1, M12-M17.

4. Lee, K. W., Kim, J. S., Oh, S. T., Kang, C. W., \& An, B. K. (2015) Effects of dietary sanguinarine on growth performance, relative organ weight, cecal microflora, serum cholesterol level and meat quality in broiler chickens. The Journal of Poultry Science, 52, 1, 15-22.

5. Hernandez, F., Madrid, J., Garcia, V., Orengo, J. and Megfas, M.D (2004) Influence of two plant extracts on broilers performance, digestibility and digestive organ size. Poultry Science, 83, 169-174.

\section{AUTHORS PROFILE}

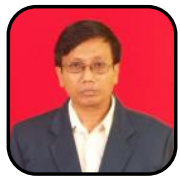

Eko Widodo, Lecturer at the Faculty of Animal Husbandry, Universitas Brawijaya. His last education was doctoratal from Gifu University, Japan. Interest in research on the use of essential oils and plant extracts as a non-antibiotic growth promoter

Derana Tri Mustikawatie, Undergraduate student, interest in Animal Nutrition and Food, Faculty of Animal Husbandry, Universitas Brawijaya

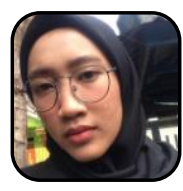

Bayu Aji Pradikdo, Masters in Animal Sciences Faculty of Animal Husbandry Universitas Brawijaya

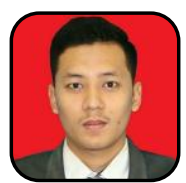

M. Halim Natsir, Lecturer at the Faculty of Animal Husbandry, Universitas Brawijaya. His Last education was doctoral from Universitas Brawijaya. Research interest is the application of encapsulation techniques in animal feed technology

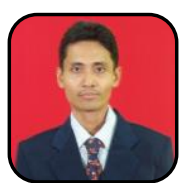

Edhy Sudjarwo, Lecturer at the Faculty of Animal Husbandry, Universitas Brawijaya. His Last education was doctoral from Universitas Brawijaya. Research interest on the influence of environmental factors on quail livestock production

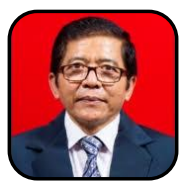

